\title{
Does the financial crisis change the effect of financing on investment? Evidence from private SMEs
}

\author{
Siraz Zubair, Rezaul Kabir*, Xiaohong Huang \\ University of Twente, the Netherlands
}

A R T I C L E I N F O

\section{Keywords:}

Financing

Investment

Financial crisis

SMEs

Private firms

\begin{abstract}
A B S T R A C T
This paper examines the real effects of the financial crisis on private firms in the Netherlands. We find that investments of small and medium-sized private enterprises declined significantly both during and after the financial crisis. We also find that investments become less dependent on internal finance than on external finance during the crisis period. However, the impacts of the two financing sources on firm investment during the postcrisis period do not differ. The findings of the study suggest that borrowing from banks remained critical in determining the investments of private SMEs during the financial crisis of 2008-2009.
\end{abstract}

\section{Introduction}

The financial crisis of 2008, regarded by many as the most serious crisis since the Great Depression of the 1930s, has brought financing and investment decisions of small businesses into sharp focus. This attention is mainly driven by the concern that a financial crisis disproportionately affects small and medium-sized enterprises (SMEs) which are widely regarded as a significant source of entrepreneurship, innovation, employment and economic growth (Ayyagari, Beck, \& Demirgüç-Kunt, 2007; Kirchhoff, Newbert, \& Hasan, 2007; Lee, Park, \& Yoon, 2010). During the crisis, private SMEs face additional restrictions and higher costs in gaining access to finance relative to large, listed firms (de la Torre, Martínez Pería, \& Schmukler, 2010). These difficulties arise from the distinct characteristics of private firms; for example, difficulty in accessing the public capital market, shorter track record, greater information asymmetry, higher failure rate, fewer opportunities available to owners-managers for wealth diversification, and typically lower availability of collateral (Beck, Demirguc-Kunt, \& Maksimovic, 2008; Danielson \& Scott, 2007; López-Gracia \& MestreBarberá, 2011; Michaelas, Chittenden, \& Poutziouris, 1999).

In this paper, we examine how the financial crisis has affected the real investments of private firms. We make three new contributions to the literature. First, we analyze the impact of two leading financing sources of SMEs: bank debt and internal finance. Private SMEs also have fewer alternative financing sources than listed firms (Becchetti, Castelli,
\& Hasan, 2010). ${ }^{1}$ Since the start of the financial crisis in 2008, commercial banks have continued to tighten the supply of bank debt, imposing further financial constraints on private firms. Worsening financial constraints can produce an adverse impact on such firms' investments. However, previous studies have not examined this problem. SMEs are also compelled to use more of their internally generated funds for new investments. Internal source of financing can thus become the dominant determinant of new investments. However, the empirical evidence for this is also lacking.

Second, we complement existing studies that focus mainly on listed firms (see Duchin, Ozbas, \& Sensoy, 2010; Almeida, Campello, \& Laranjeira, 2011; Nguyen, Nguyen, \& Xiangkang, 2015 for the United States, and Bo, Driver, \& Lin, 2014 for China) and analyze survey data (Danielson \& Scott, 2007; Gregory, Rutherford, Oswald, \& Gardiner, 2005). However, for private firms, the empirical evidence remains scarce. Vermoesen, Deloof, and Laveren (2013) and Akbar, Rehman, and Ormrod (2013) analyze SMEs in Belgium and the United Kingdom. Previous studies also examined just one or two of the crisis years (Duchin et al., 2010; Akbar et al., 2013; Vermoesen et al., 2013), and do not relate investment to the various sources of financing. We analyze the financial statement data of private firms and cover a longer time period, namely 2004-2012.

The third contribution of the study comes from our focus on private firms in the Netherlands. During the financial crisis, the Dutch economy experienced severe shocks; various economic indicators such as the

\footnotetext{
*Corresponding author at: Department of Finance and Accounting, Faculty of Behavioral, Management and Social Sciences, University of Twente, P. O. Box 217, 7500 AE Enschede, the Netherlands.

E-mail addresses: s.m.zubair@utwente.nl (S. Zubair), r.kabir@utwente.nl (R. Kabir), x.huang@utwente.nl (X. Huang).

${ }^{1}$ Although other financing sources like trade credit, private equity, leasing, government grants, informal lending, can exist, these two sources are considered to be the most important for SMEs.
} 
gross domestic product, government debt, import, and export revenues showed significant deteriorations while the unemployment rate increased. The Netherlands suffered an extended aftermath of the financial crisis, and SMEs that primarily depend on banks for financing were hit harder than large businesses. ${ }^{2}$ The results of our study provide insights into the effects of financial crisis on a small open economy in which private firms continue to be the main driver of its economic growth.

The remainder of the paper is organized as follows. The second section presents the theories and hypotheses. In the third section, we describe the research methodology, which is followed by a description of the data. The empirical results of the study are presented in the fifth section. The final section summarizes the findings and conclusions of the paper.

\section{Theories and hypotheses}

Several theories are used to explain the investment behavior of firms. The Q-theory asserts that firms undertake investments when valuable growth opportunities exist (Rousseau \& Kim, 2008). According to the asymmetric theory of investment, imperfections in the financial markets lead firms to face varying degrees of financing constraints and therefore undertake varying levels of investments (Kasahara, 2008). Since a financial crisis is associated with lower growth opportunities and higher financial constraints, both theories predict declines in investment during a financial crisis. Kahle and Stulz (2013) argue that bank supply, credit supply, and demand shocks during a crisis create considerable uncertainty and force firms to reduce their capital investment. We expect all these effects to be more pronounced for private firms relative to public firms.

Studies examine numerous empirical effects of financial crisis. Kim, Lee, and Park (2002) and Rousseau and Kim (2008) focus on the Korean financial crisis and observe contractions in the credit market. The negative effect of credit supply contraction is also documented by Akiyoshi and Kobayashi (2010) for Japan. Chen and Hsu (2005) find that during the Asian financial crisis, SMEs experience greater output decline than large firms. In the context of the recent financial crisis, Ogawa and Tanaka (2013) analyze the survey data of Japanese SMEs and identify the various types of shocks - demand, supply and financial shocks - faced by the firms. As for the impact on investment, Duchin et al. (2010) and Kahle and Stulz (2013) observe that the credit crisis has negatively affected publicly-listed firms in the USA. Akbar et al. (2013) and Vermoesen et al. (2013) report similar findings for private firms in the UK and Belgium, respectively.

Overall, shocks arising from the financial crisis typically cause private firms to reduce their investments. Even though firms still have growth opportunities, they may not undertake new investment due to increased uncertainties and a lack of financing. Therefore, our first hypothesis is:

H1. Investments of private firms decline following the onset of the financial crisis.

Financing of investment comes either from internal sources

\footnotetext{
${ }^{2}$ According to the 2014 SBA Fact Sheet of the European Union, the proportion of Dutch SMEs with rejected or unacceptable loan requests was almost 39 percent in 2013 compared to the EU average of 14 percent. The proportion of SMEs reporting deterioration in the willingness of banks to provide loans stood at 39 percent in 2013 compared with 25 percent in the EU. The cost of borrowing for small loans relative to large loans which was 6 percent in 2007 on the eve of the financial crisis, reached an all-time high of 44 percent in 2013, far above the EU average of 24 percent. The Fact Sheet also reports that Dutch SMEs find it much harder to secure bank financing, and even if they do they are charged a much higher interest rates than their EU peers. Source: http://ec. europa.eu/enterprise/policies/sme/facts-figures-analysis/performance-review/ files/countries-sheets/2010-2011/netherlands_en.pdf.
}

(operating income, retained earnings) or external sources (new equity, borrowing), or a combination of the two. Firms must evaluate and choose the most suitable source of finance as the different sources have their own benefits and costs. Existing theoretical models of adverse selection and moral hazard advocate the cost advantages of internal finance over external finance for companies that face uncertain prospects and operate in imperfect capital markets (Wang, 2010; Yang, Baker, Chou, \& Lu, 2009). Although the common theoretical principles underlying the financing decisions of large listed firms also apply to private firms, Du, Guariglia, and Newman (2015) describe financing choices as among the most challenging and problematic decisions faced by SMEs. According to the pecking order theory, a firm has a clear order of preference for financing: firstly, internally generated finance, then debt, and finally, equity (Agliardi, Agliardi, \& Spanjers, 2016). The theory argues that, because of the costs associated with information asymmetry, agency problems, and control restrictions between owners and managers, firms tend to prefer internal finance over external finance. If external finance is required, debt is preferred to equity. Many studies (Degryse, de Goeij, \& Kappert, 2012; Gregory et al., 2005; Sogorb Mira, 2005) consider the pecking order theory as more relevant to SMEs.

How is the financing behavior of a firm related to its investment? Market imperfections usually lead a firm's investment and financing decisions to interact with each other. One of the first studies that examined the effect of market imperfections on investment was that of Fazzari, Hubbard, and Petersen (1988). The authors argue that an increase in asymmetric information causes an increase in the cost of obtaining external finance (e.g., issuing new debt or new equity). Therefore, firms have an incentive to use internal finance for investment. It is only when internal finance is insufficient that firms need to use externally generated finance to continue their investment. Hence, the investment of a firm depends substantially on the funds it is able to generate internally.

Small and medium-sized firms are particularly dependent on banks for external finance (Berger \& Udell, 1998; Petersen \& Rajan, 1994). Small fluctuations in the supply of bank finance have significant impacts on their investments. Bigelli, Martín-Ugedo, and Sánchez-Vidal (2014) argue that private firms are generally characterized by higher debt ratios and a higher proportion of short-term debt compared to long-term debt as compared to large companies. When a financial crisis is underway, these firms face higher financial constraints because of increased difficulties in accessing alternative sources of finance (Akiyoshi \& Kobayashi, 2010). Consequently, internally generated funds become a distinct financing source for private firms during the financial crisis. Such firms will be highly dependent on internal funds to finance their investments. Therefore, our second hypothesis is:

H2. Investments of private firms become more dependent on internal finance than external finance as a result of the financial crisis.

\section{Methodology}

We use the standard investment model that includes a firm's cash flow, size and growth opportunity as the main explanatory variables to test our hypotheses (Badertscher, Shroff, \& White, 2013; Yang et al., 2009). We estimate the following fixed effects regression model:

$\begin{aligned} \text { Investment }_{i t}= & \alpha+\beta_{1} \text { Crisis }+\beta_{2} \text { Post-crisis }+\beta_{3} \text { Cash Flow } \text { Fit } \\ & +\beta_{4} \text { Size }_{i t}+\beta_{5} \text { Growth }_{i t}+\text { Firm }_{i}+\varepsilon_{i t}\end{aligned}$

where the subscript $i$ denotes individual firms and $t$ denotes different years. Crisis is a dummy variable equal to 1 for the period 2008-2009, and 0 otherwise; and Post-crisis is a dummy variable equal to 1 for the period 2010-2012, and 0 otherwise. For Hypothesis 1 , we test the two regression coefficients $\beta_{1}$ and $\beta_{2}$ to see whether firm investment differs significantly during the crisis and post-crisis periods. 
Table 1

Variable definitions.

\begin{tabular}{ll}
\hline Variables & Definitions \\
\hline Investment_1 & Change in fixed assets plus depreciation over beginning-of-year total assets \\
Investment_2 & Increase in fixed assets plus depreciation over beginning-of-year total assets \\
Investment_3 & Change in tangible fixed assets plus depreciation over beginning-of-year total assets \\
Investment_4 & Increase in tangible fixed assets plus depreciation over beginning-of-year total assets \\
Cash Flow & Operating income plus depreciation over beginning-of-year total assets \\
Internal Finance & Income after tax plus depreciation over beginning-of-year total assets \\
External Finance & Change in bank debt over beginning-of-year total assets \\
Size & Natural logarithm of the book value of total assets \\
Growth & Logarithmic change in annual employment \\
Crisis & Dummy variable equal to 1 for the period 2008-2009, 0 otherwise \\
Post-crisis & Dummy variable equal to 1 for the period 2010-2012, 0 otherwise
\end{tabular}

We measure investment using four robust constructs. Investment_ 1 is computed as the annual change in fixed assets plus depreciation (Firth, Malatesta, Xin, \& Xu, 2012). Investment_2 is calculated as the annual increase in fixed assets plus depreciation (Badertscher et al., 2013). The difference between Investment_1 and Investment_2 is that the former includes the reduction in and/or sale of fixed assets (negative investment) while the latter variable considers only the increase in and/or purchase of fixed assets. Another way to measure investment is to consider tangible fixed assets (Akbar et al., 2013; Guariglia, 2008) and intangible fixed assets (Bigelli et al., 2014). However, since most of the private firms in our sample do not disclose information on intangible fixed assets, we define investment variables based on tangible fixed assets. Investment 3 is computed as the annual change in tangible fixed assets plus depreciation (Mortal \& Reisel, 2013) and Investment_4 is computed as the annual increase in tangible fixed assets plus depreciation (Asker, Farre-Mensa, \& Ljungqvist, 2015; Badertscher et al., 2013). All values are divided by total assets at the beginning of the year.

Cash Flow and Growth are the two widely used variables to explain firm investment. We define Cash Flow as operating income plus depreciation divided by total assets at the start of the year (Duchin et al., 2010). Following previous research on SMEs (Honjo \& Harada, 2006; Rahaman, 2011), the variable Growth is defined as the rate of annual growth in employment. We include firm size (Size) as an influential control variable, and define it as the natural logarithm of total assets. Since commercial banks usually consider the size of a business an important criterion for financing decisions, and investments of smaller firms can be significantly different than those of larger firms, it is important to account for this effect. All explanatory and control variables are calculated at the beginning of the year to mitigate the endogeneity problem. All variables used in the study are defined in Table 1.

We analyze a long time period covering the years before, during, and after the financial crisis. The presence of panel data has the advantage that we can control for all time-invariant firm-specific factors, both observed and unobserved, by using firm fixed effects (Bastos \& Pindado, 2013). To find the most suitable panel estimator, we first use the Breusch and Pagan test statistic to compare random effects with standard ordinary least squares regression and then use the Hausman test to compare the random effects with the fixed effects model. It turns out that the fixed effects panel estimation is most suitable for our analysis. Previous studies examining the investment behavior of small and private firms also used the fixed effects estimation method (Akbar et al., 2013; Vermoesen et al., 2013).

To examine whether the financial crisis has led to a change in the way internal and external financing influence investment, we use a slightly modified version of specification (1) and estimate the following regression model:

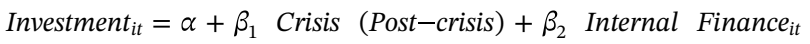

$$
\begin{aligned}
& +\beta_{3} \text { External Finance }_{i t}+\beta_{4} \text { Internal } \text { Finance }_{i t} \\
& * \text { Crisis (Post-crisis })+\beta_{5} \text { External } \text { Finance }_{i t} * \text { Crisis } \\
& (\text { Post-crisis })+\beta_{6} \text { Size }_{i t}+\beta_{7} \text { Growth }_{i t}+\text { Firm }_{i}+\varepsilon_{i t}
\end{aligned}
$$

This regression model is estimated separately for the crisis and the post-crisis periods. The coefficients of interest are the two interaction coefficients $\beta_{4}$ and $\beta_{5}$, which capture the change in the effect of internal and external finance, respectively on a firm's investment during the crisis (post-crisis) period. We apply the Wald test to compare whether the marginal impact of the two different financing sources differs statistically.

We define internal finance as after-tax income plus depreciation over beginning-of-year total assets (Guariglia, 2008). To be consistent with the definition of internal finance, we use net bank debt as the measure of external finance, which is defined as the change in bank debt over beginning-of-year total assets (Nguyen et al., 2015). ${ }^{3}$

To gain an insight into the magnitude of the effect of the several financing sources, we also conduct separate regressions across various sub-periods, instead of interacting the financing variables with the crisis and post-crisis dummies. This approach has the advantage that the parameters of the control variables vary across different periods, and show the effect of financing over various periods (Rousseau \& Kim, 2008).

To verify the robustness of fixed effects estimation results, we re-run our tests with pooled ordinary least squares (OLS) regressions. However, a concern about the potential endogeneity of investment with respect to internal finance remains. Therefore, we adopt the two-stage least squares (2SLS) regressions method. In the first stage regression, we use the previous year's internal finance as an instrument. The predicted internal finance from the first stage estimation is used as the independent internal finance in the second stage equation.

\section{Data}

We collect financial statement data of Dutch private firms over the period 2004-2012 from Bureau van Dijk's REACH database. Laeven and Valencia (2012) state that the global financial crisis started in 2008 in most European countries, whereas the inception of the crisis was in 2007 for the USA and the UK. We consider the years 2008-2009 as the period of the financial crisis and the years $2010-2012$ as the post-crisis period.

We follow the definition of the European Commission which classifies a firm into a small category when it has between 10-49 employees

\footnotetext{
${ }^{3}$ We did not include new equity issues as part of external finance because prior studies indicated bank credit as the main source of external finance for SMEs (Petersen \& Rajan, 1994; Berger \& Udell, 1998; Beck et al., 2008).
} 
and $€ 2-€ 10$ million revenue or total assets, and medium category when it has between 50 and 249 employees with a maximum $€ 50$ million revenue or $€ 43$ million total assets. A firm is included in the sample only when it satisfies at least two of these three conditions (employee number, revenue, and total assets) over the pre-crisis period. We did not identify and include firms as SMEs from the crisis and post-crisis periods in the sample because a firm may become an SME due to the adverse effect of the financial crisis whereas the main objective of our study is to investigate the investment behavior of existing SMEs during the crisis. Thus, no new firm enters the sample during or after the crisis period. Since a few firms have missing information for the crisis and the post-crisis periods, we do not have a balanced panel.

As is common in the literature, firms operating in the financial sector (banks, insurance companies, public investment trusts), nonprofit organizations and governmental enterprises are excluded from the analysis because non-business considerations primarily influence their decisions. Following Duchin et al. (2010) and Vermoesen et al. (2013), firms whose total assets doubled during one of the years of the sample period and those firms with negative equity are excluded to omit the effects of mergers and acquisitions or other significant restructurings. Firms publishing consolidated accounts are analyzed to allow a comparison across the results of previous studies. The final sample of the study includes 469 private firms. We winsorize all firmspecific variables at the 1st percentile in each tail to exclude the influence of outliers.

Table 2 presents the industrial distribution of the firms in the sample. The largest category of the sample consists of wholesale and retail firms (26 percent). A substantial number of firms operate in the heavy manufacturing (21 percent), construction (20 percent), light manufacturing (16 percent), and transportation (11 percent) industries. The other category of only 2 percent of firms consists of private firms operating in the agricultural and mining sectors.

\subsection{Summary statistics}

For the full period (2004-2012) and all firms in the sample, we find that investment, as a percentage of total assets, ranges from 4.4 percent to 7.7 percent for the mean and 2.2 percent to 4.3 percent for the median (unreported table). These are slightly lower than those for the Belgian SMEs with 7.9 percent for the mean and 5.1 percent for the median reported by Vermoesen et al. (2013), probably due to our longer sample period and our scaling with beginning-year total assets. We present the summary statistics (the means and the medians) of all variables separately for the pre-crisis, crisis, and post-crisis periods in Table 3. We also present the differences of these variables across subperiods. The variables expressed in ratios are presented in Panel A. We observe that Dutch SMEs invest (Investment_1) on average 4.2 percent of their assets during the crisis period, which represents a decline of 1.3 percentage points from the pre-crisis period. Firm investment continues to decline by 0.7 percentage points in the post-crisis period, giving a total decline of 2 percentage points compared to the pre-crisis period.

The average firm has an External Finance (change in bank debt over total assets) level of 4.1 percent in the pre-crisis period. Looking at the

Table 2

Industry classification.

\begin{tabular}{lll}
\hline Industry & No. of firms & $\%$ of firms \\
\hline Agricultural and mining & 10 & 2 \\
Construction & 93 & 20 \\
Light manufacturing & 73 & 16 \\
Heavy manufacturing & 98 & 21 \\
Transportation & 51 & 11 \\
Wholesale and retail trade & 121 & 26 \\
Services & 23 & 5 \\
Total & 469 & 100 \\
\hline
\end{tabular}

effects of the financial crisis, we see that External Finance declined significantly by 4.8 percentage points from the pre-crisis period. The median figure also indicates a significant decline (4.4 percentage points). However, the corresponding reduction in Internal Finance is lower (mean $=2.2$ percent; median $=2.3$ percent). Additional calculations indicate that the sample firm relies on, on average, 55.5 percent bank finance (sum of short-term and long-term bank debt over total assets $)^{4}$, compared to 34 percent in the UK, reflecting the difference between a predominantly bank-based and a predominantly market-based financial system. Our finding is in line with that of de Goeij and Duffhues (2010). They analyze several pre-crisis years and report that in the Netherlands, SMEs are financed more by debt relative to large firms. The fact that more than half of the assets of Dutch SMEs are financed by banks indicates the difficulty that SMEs face in accessing public capital markets and their limited availability of internal finance.

The summary statistics of variables defined in levels are presented in Panel B. The average (median) level of firm investment (Investment_1), measured by the change in fixed assets including depreciation, changes from $€ 822$ thousand before the crisis to $€ 662$ thousand during the crisis and $€ 602$ thousand after the crisis. Looking at the effect of the financial crisis, we observe that the average firm takes on new bank debt of $€ 344$ thousand before the crisis, but during the crisis, the firm repays $€ 242$ thousand of bank debt. The finding is in line with that of Psillaki and Eleftheriou (2015) who examine a sample of French SMEs and find that their access to external financing sources underwent significant change during the financial crisis. The amount of internal finance also declines from $€ 1547$ thousand before the crisis to $€ 1409$ thousand during the crisis.

\subsection{Correlation}

Table 4 presents the Pearson correlation coefficients between the variables. By definition, the change and the increase (namely, the positive change) in assets are perfectly correlated, as can be seen between Investment_ 1 and Investment_2, and between Investment_3 and Investment_4. The change in fixed assets and the change in tangible fixed assets are also highly correlated. Investment shows, as expected, a significant positive correlation with Cash flow and Growth. We also observe that SMEs that invest the most tend to use the most bank debt (correlation $=0.35$ ) and internal finance (correlation $=0.23$ ). Table 4 also shows that Internal Finance has a low correlation with External Finance (correlation $=0.09$ ).

The correlations among the independent variables are generally low (the highest correlation is 0.19 ) suggesting that multicollinearity is not a serious concern in our study. Yet, in most empirical analyses, the inclusion of several variables into a single regression raises a concern that there is multicollinearity that may lead to spurious results (Francis, Hasan, \& Wu, 2012). We estimate Variance Inflation Factor (VIF) - a widely used measure to identify the degree of multicollinearity. According to Gujarati (2012), a VIF value greater than 10 indicates multicollinearity. Almeida and Eid (2014) use a VIF of less than 5 as indicating no multicollinearity. The VIF calculated for each independent variable included in our models is less than 2 , which is well below that proposed threshold indicator. Therefore, multicollinearity is not a concern in our study.

\section{Empirical results}

We first investigate whether private SMEs in the Netherlands experienced a significant reduction in investment as a result of the financial crisis. Table 5 presents the empirical results. Model (1) is the baseline regression incorporating Crisis, Post-crisis and firm fixed effects

\footnotetext{
${ }^{4}$ Not reported in the table.
} 
Table 3

Summary statistics.

Panel A: Means, medians, and the differences of variables as defined in Table 1.

\begin{tabular}{|c|c|c|c|c|c|c|c|c|c|c|}
\hline & \multicolumn{2}{|c|}{$\begin{array}{l}\text { Pre-crisis } \\
(2004-2007)\end{array}$} & \multicolumn{2}{|c|}{$\begin{array}{l}\text { Crisis } \\
(2008-2009)\end{array}$} & \multicolumn{2}{|c|}{$\begin{array}{l}\text { Post-crisis } \\
(2010-2012)\end{array}$} & \multicolumn{2}{|c|}{$\begin{array}{l}\text { Difference: } \\
\text { Crisis - Pre-crisis }\end{array}$} & \multicolumn{2}{|c|}{$\begin{array}{l}\text { Difference: } \\
\text { Post-crisis - Crisis }\end{array}$} \\
\hline & Mean & Median & Mean & Median & Mean & Median & Mean & Median & Mean & Median \\
\hline Investment_1 & 0.055 & 0.031 & 0.042 & 0.019 & 0.035 & 0.016 & $-0.013^{* *}$ & $-0.012^{*}$ & -0.007 & -0.003 \\
\hline Investment_2 & 0.086 & 0.050 & 0.076 & 0.041 & 0.065 & 0.033 & $-0.010^{* * *}$ & $-0.009^{*}$ & $-0.011^{* \star *}$ & $-0.008 *$ \\
\hline Investment_3 & 0.053 & 0.029 & 0.042 & 0.019 & 0.033 & 0.015 & $-0.011^{* \text { *k }}$ & $-0.010^{*}$ & $-0.009^{* *}$ & $-0.004 *$ \\
\hline Investment_4 & 0.073 & 0.043 & 0.067 & 0.034 & 0.057 & 0.030 & $-0.006^{*}$ & $-0.009^{*}$ & $-0.010^{* *}$ & $-0.004 *$ \\
\hline Cash Flow & 0.149 & 0.135 & 0.115 & 0.100 & 0.100 & 0.085 & $-0.034^{* *}$ & $-0.035^{*}$ & $-0.015^{* *}$ & $-0.004 *$ \\
\hline Internal Finance & 0.114 & 0.102 & 0.092 & 0.079 & 0.082 & 0.069 & $-0.022^{* *}$ & $-0.023^{*}$ & $-0.010^{\text {*ik }}$ & $-0.010^{*}$ \\
\hline External Finance & 0.041 & 0.018 & -0.007 & -0.026 & 0.010 & -0.003 & $-0.048^{* *}$ & $-0.044^{*}$ & $0.017^{* k *}$ & $0.023^{*}$ \\
\hline Size & 9.479 & 9.513 & 9.598 & 9.614 & 9.592 & 9.630 & $0.119^{* * *}$ & $0.101^{*}$ & -0.006 & 0.016 \\
\hline Growth & 0.013 & 0.000 & -0.004 & 0.000 & -0.008 & -0.006 & $-0.017^{* *}$ & $0.000^{*}$ & -0.004 & -0.006 \\
\hline
\end{tabular}

Panel B: Means, medians, and the differences of variables expressed in thousands of Euros, except the number of employees.

\begin{tabular}{|c|c|c|c|c|c|c|c|c|c|c|}
\hline & \multicolumn{2}{|c|}{$\begin{array}{l}\text { Pre-crisis } \\
(2004-2007)\end{array}$} & \multicolumn{2}{|c|}{$\begin{array}{l}\text { Crisis } \\
(2008-2009)\end{array}$} & \multicolumn{2}{|c|}{$\begin{array}{l}\text { Post-crisis } \\
(2010-2012)\end{array}$} & \multicolumn{2}{|c|}{$\begin{array}{l}\text { Difference: } \\
\text { Crisis - Pre-crisis }\end{array}$} & \multicolumn{2}{|c|}{$\begin{array}{l}\text { Difference: } \\
\text { Post-crisis - Crisis }\end{array}$} \\
\hline & Mean & Median & Mean & Median & Mean & Median & Mean & Median & Mean & Median \\
\hline Investment_1 & 821.92 & 349.00 & 661.88 & 251.00 & 601.61 & 199.5 & $-160.04^{* *}$ & $-98.00^{k * k}$ & -60.26 & -51.50 \\
\hline Investment_2 & $1,260.89$ & 575.50 & $1,227.17$ & 534.50 & $1,095.29$ & 505.00 & -33.71 & -41.00 & 131.88 & $-29.50 *$ \\
\hline Investment_3 & 768.31 & 332.00 & 694.75 & 258.00 & 552.99 & 203.00 & -73.57 & $-74.00^{* * *}$ & $-141.75^{k *}$ & $-55.00^{* k}$ \\
\hline Investment_4 & 1068.02 & 492.50 & $1,102.48$ & 480.50 & 940.29 & 379.00 & 34.45 & -12.00 & $-162.18^{k * \hbar}$ & $-101.50^{* * *}$ \\
\hline Cash Flow & $2,010.26$ & 1567.50 & $1,789.12$ & 1468.00 & 1.644 .05 & 1223.00 & $-221.14^{* *}$ & $-99.50^{\text {** }}$ & $-145.06^{*}$ & $-245.00^{\text {** }}$ \\
\hline Internal Finance & $1,547.28$ & 1191.00 & $1,409.13$ & 1089.00 & $1,318.35$ & 953.50 & $-138.15^{* *}$ & $-102.00^{* * *}$ & -90.78 & $-135.50 *$ \\
\hline External Finance & 344.52 & 208.00 & -241.86 & -353.00 & 66.99 & -56.5 & $-585.39^{* *}$ & $-561.00^{\text {*k* }}$ & $308.86^{* * *}$ & $296.50^{* * 4}$ \\
\hline Size & $15,585.15$ & 13535.00 & $17,455.63$ & 14966.50 & $17,517.81$ & 15216.00 & $1,870.48^{\text {k* }}$ & $1431.00^{* * *}$ & 62.18 & 249.5 .0 \\
\hline No. of Employees & 114 & 111 & 118 & 109 & 114 & 106 & 4 & -2 & -4 & -3 \\
\hline
\end{tabular}

** and * indicate significance at the 5 percent and 10 percent level, respectively.

Table 4

Correlation matrix.

\begin{tabular}{|c|c|c|c|c|c|c|c|c|c|}
\hline & (1) & (2) & (3) & (4) & (5) & (6) & (7) & (8) & (9) \\
\hline (1) Investment_1 & 1 & & & & & & & & \\
\hline (2) Investment_2 & 1 & 1 & & & & & & & \\
\hline (3) Investment_3 & $0.87 *$ & $0.88 *$ & 1 & & & & & & \\
\hline (4) Investment_4 & $0.86^{*}$ & $0.90^{*}$ & 1 & 1 & & & & & \\
\hline (5) Cash Flow & $0.20 *$ & $0.15^{*}$ & $0.23^{*}$ & $0.15^{*}$ & 1 & & & & \\
\hline (6) Internal Finance & $0.23 *$ & $0.17 *$ & $0.25^{*}$ & $0.17^{*}$ & $0.95^{*}$ & 1 & & & \\
\hline (7) External Finance & $0.35^{*}$ & $0.38^{*}$ & $0.34 *$ & $0.34^{*}$ & $0.12 *$ & $0.09^{*}$ & 1 & & \\
\hline (8) Size & $0.09 *$ & $0.11 *$ & $0.08^{*}$ & 0.10 * & $-0.08 *$ & $-0.09 *$ & $0.06^{*}$ & 1 & \\
\hline (9) Growth & $0.11 *$ & $0.08 *$ & $0.13^{*}$ & $0.08^{*}$ & $0.19^{*}$ & $0.15^{*}$ & $0.19 *$ & -0.001 & 1 \\
\hline
\end{tabular}

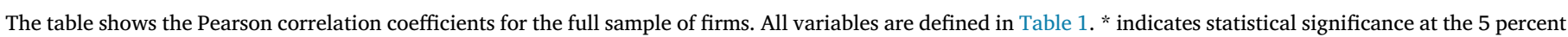
level.

only, whereas Model (4) is the extended regression showing all three firm-level control variables (Cash flow, Size, and Growth) as well as Crisis, Post-crisis and firm fixed effects. Overall, the results reveal a statistically significant decline in investment both during and after the financial crisis. Model (4) shows that annual investment as a percentage of total assets for the average firm declined by 1.8 percentage points during the crisis and by 2.3 percentage points in the post-crisis period. From all the regression results presented in Table 5, we can conclude that investment of private firms in the Netherlands was clearly affected by the financial crisis. The results support Hypothesis 1 . This finding is in line with that of Vermoesen et al. (2013) who examined SMEs from Belgium, and that of Akbar et al. (2013) who investigated private firms in the UK.

In all the regressions, the variables Cash Flow, Size, and Growth have significantly positive coefficients. Overall, these results suggest that firms that have high cash flow and high growth, and larger SMEs undertake more investment. The adjusted $\mathrm{R}^{2}$ for the regression that includes all variables (Model 4) is 17 percent, which is slightly higher than that reported by Vermoesen et al. (2013) and similar to that reported by Akbar et al. (2013). The F-statistics across all models are statistically significant, indicating that the estimated models explain well the variation in firm investment.

We next proceed to examine Hypothesis 2: whether the two financing sources (Internal Finance and External Finance) differentially affect the investment of small and medium-sized enterprises during both the crisis and post-crisis periods. Therefore, we perform regressions interacting both financing sources using crisis and post-crisis dummies. We present these results in Table 6, Panel A.

In Models (1) and (2), we observe negative and statistically significant interaction coefficients of Internal Finance * Crisis. The results show that the effect of internal financing on investment declines significantly during the crisis. On the other hand, we do not find any significant change in the impact of external financing on investment during the crisis period, as can be seen from the statistically insignificant coefficients of External Finance * Crisis. Conducting the Wald tests on these two interaction coefficients (p-values $=0.001$ and 0.001 ) leads us to conclude that the marginal impact of internal financing on a firm's investment during the crisis is significantly smaller than that of external 
Table 5

Effect of the financial crisis on investment.

\begin{tabular}{|c|c|c|c|c|}
\hline & (1) & (2) & (3) & (4) \\
\hline Crisis & $\begin{array}{l}-0.014^{\text {t****x }} \\
(-3.51)\end{array}$ & $\begin{array}{l}-0.007^{*} \\
(-1.77)\end{array}$ & $\begin{array}{l}-0.017^{\text {*k.k }} \\
(-4.38)\end{array}$ & $\begin{array}{l}-0.018^{\text {k**kt }} \\
(-3.93)\end{array}$ \\
\hline Post-crisis & $\begin{array}{l}-0.020^{\text {**** }} \\
(-5.45)\end{array}$ & $\begin{array}{l}-0.011^{\text {***k }} \\
(-2.91)\end{array}$ & $\begin{array}{l}-0.022^{* * * * k} \\
(-5.83)\end{array}$ & $\begin{array}{l}-0.023^{\text {k*k* }} \\
(-5.31)\end{array}$ \\
\hline Cash Flow & & $\begin{array}{l}0.172^{\text {. }} \\
(9.25)\end{array}$ & $\begin{array}{l}0.151^{* * *} \\
(8.26)\end{array}$ & $\begin{array}{l}0.100^{\text {*kx }} \\
(4.83)\end{array}$ \\
\hline Size & & & $\begin{array}{l}0.082^{* * * * *} \\
(11.70)\end{array}$ & $\begin{array}{l}0.077^{\text {*t*k** }} \\
(9.34)\end{array}$ \\
\hline Growth & & & & $\begin{array}{l}0.042^{*} \\
(1.65)\end{array}$ \\
\hline Firm fixed effects & Yes & Yes & Yes & Yes \\
\hline No. of Observations & 3960 & 3915 & 3915 & 3030 \\
\hline Adjusted $\mathrm{R}^{2}$ & 0.112 & 0.133 & 0.166 & 0.170 \\
\hline F-statistic & 16.21 & 38.71 & 64.43 & 30.77 \\
\hline P-value (F-statistic) & 0.000 & 0.000 & 0.000 & 0.000 \\
\hline
\end{tabular}

The table reports the estimates of firm fixed effects regressions of Investment_1. All variables are defined in Table 1. t-statistics are reported in parentheses. ${ }^{* * *}$, ${ }^{* *}$, and * indicate statistical significance at the 1 percent, 5 percent, and 10 percent levels, respectively

financing during the crisis. In other words, firms become less dependent on internal finance than on external finance during the financial crisis.

We now examine whether investment is more dependent on internal finance in the post-crisis period (2010-2012). Models (3) and (4) present the result. In both models, the interaction coefficients of Internal Finance with Post-crisis dummy show a significant positive impact. However, the effect of external finance during the post-crisis period remains unchanged. The Wald tests ( $p$-values $=0.203$ and 0.139 ) show that the differences between the coefficients of Internal Finance * Postcrisis and External Finance * Post-crisis in Models (3) and (4) are statistically insignificant. Thus, we conclude that the marginal impacts of the two financing sources on investment during the post-crisis period do not differ. Therefore, based on the results for the crisis and post-crisis periods, we reject Hypothesis 2.

As an alternative way of examining which financing source, internal or external, is more influential on investment decisions, we perform separate regressions for the pre-crisis, crisis, and post-crisis periods. These results are presented in Table 6, Panel B. For the pre-financial crisis period (2004-2007), we observe a positive relationship between internal finance and investment, as well as between external finance and investment. On the other hand, during the crisis period (2008-2009), Internal Finance is no longer related to Investment. However, the level of SME investment is still significantly determined by external finance. The post-crisis period results are analogous to the precrisis period: both Internal Finance and External Finance show a significant positive relationship with Investment.

Taken together, these findings are consistent with those reported in Panel A. The financial crisis has significantly reduced the influence of internal financing on SME's total investments, but has not changed the significant positive relationship between external financing and total investment. Although this finding is not in line with our hypothesis, it is quite plausible that private SMEs may not be willing to risk internal funds when the financial crisis has made investments increasingly uncertain. These firms usually have a few large shareholders who tend to behave in a risk averse manner because their wealth is highly concentrated. While facing uncertainty due to the financial crisis, these shareholders may not be willing to provide new financing to fund investments unless they are also supported by providers of debt financing.

\subsection{Additional analysis}

The previous results are obtained from employing panel regression with fixed effects estimations. We now examine if the results related to Hypothesis 2 are robust to alternative estimation techniques. The
Table 6

Effect of internal and external finance on investment.

\begin{tabular}{|c|c|c|c|c|}
\hline \multicolumn{5}{|l|}{ Panel A: Interaction analysis } \\
\hline & (1) & (2) & (3) & (4) \\
\hline Crisis & $\begin{array}{l}0.016^{\text {rkxk }} \\
(3.35)\end{array}$ & $\begin{array}{l}0.018^{\text {k.kik }} \\
(3.06)\end{array}$ & & \\
\hline Post-crisis & & & $\begin{array}{l}-0.013^{* * * *} \\
(-2.88)\end{array}$ & $\begin{array}{l}-0.019^{\text {*k*k }} \\
(-3.72)\end{array}$ \\
\hline Internal Finance & $\begin{array}{l}0.259^{\text {*t*k*k }} \\
(11.34)\end{array}$ & $\begin{array}{l}0.218^{\text {***** }} \\
(8.59)\end{array}$ & $\begin{array}{l}0.201^{k * k * k} \\
(8.38)\end{array}$ & $\begin{array}{l}0.142^{k \cdot k \hat{k}} \\
(5.22)\end{array}$ \\
\hline External Finance & $\begin{array}{l}0.200^{\text {k.kk }} \\
(18.53)\end{array}$ & $\begin{array}{l}0.205^{\text {k.k.k }} \\
(16.31)\end{array}$ & $\begin{array}{l}0.199^{\text {knk }} \\
(18.76)\end{array}$ & $\begin{array}{l}0.199^{\text {knk }} \\
(15.96)\end{array}$ \\
\hline Internal Finance * Crisis & $\begin{array}{l}-0.126^{* * *} \\
(-3.39)\end{array}$ & $\begin{array}{l}-0.158^{* * * *} \\
(-3.84)\end{array}$ & & \\
\hline Internal Finance * Post-crisis & & & $\begin{array}{l}0.073^{k * k} \\
(2.09)\end{array}$ & $\begin{array}{l}0.099^{k k k} \\
(2.58)\end{array}$ \\
\hline External Finance * Crisis & $\begin{array}{l}0.020 \\
(0.92)\end{array}$ & $\begin{array}{l}0.005 \\
(0.21)\end{array}$ & & \\
\hline External Finance * Post-crisis & & & $\begin{array}{l}0.020 \\
(0.88)\end{array}$ & $\begin{array}{l}0.030 \\
(1.21)\end{array}$ \\
\hline Size & & $\begin{array}{l}0.025^{\text {t*k*k }} \\
(3.17)\end{array}$ & & $\begin{array}{l}0.024^{* * * * *} \\
(2.96)\end{array}$ \\
\hline Growth & & $\begin{array}{l}-0.001 \\
(-0.05)\end{array}$ & & $\begin{array}{l}-0.005 \\
(-0.23)\end{array}$ \\
\hline Firm fixed effects & Yes & Yes & Yes & Yes \\
\hline No. of Observations & 3901 & 3024 & 3901 & 3024 \\
\hline Adjusted $\mathrm{R}^{2}$ & 0.249 & 0.272 & 0.248 & 0.272 \\
\hline F-statistic & 132.7 & 76.48 & 131.6 & 76.53 \\
\hline P-value (F-statistic) & 0.000 & 0.000 & 0.000 & 0.000 \\
\hline $\begin{array}{l}\text { P-value (Wald test) for the } \\
\text { difference of interaction } \\
\text { coefficients for the } \\
\text { respective period }\end{array}$ & 0.001 & 0.001 & 0.203 & 0.139 \\
\hline
\end{tabular}

Panel B: Sub-period analysis

\begin{tabular}{|c|c|c|c|}
\hline & $\begin{array}{l}\text { Pre-crisis period } \\
(2004-2007)\end{array}$ & $\begin{array}{l}\text { Crisis period } \\
(2008-2009)\end{array}$ & $\begin{array}{l}\text { Post-crisis period } \\
(2010-2012)\end{array}$ \\
\hline \multirow[t]{2}{*}{ Internal Finance } & $0.095^{*}$ & -0.082 & $0.179^{* * * *}$ \\
\hline & $(1.94)$ & $(-1.04)$ & (3.54) \\
\hline \multirow[t]{2}{*}{ External Finance } & $0.144^{* * * * x}$ & $0.178^{* \star * * k}$ & $0.200^{* * * * k}$ \\
\hline & (7.59) & $(5.18)$ & (8.73) \\
\hline \multirow[t]{2}{*}{ Size } & $0.088^{* * * *}$ & 0.049 & $0.109^{* * * *}$ \\
\hline & $(4.77)$ & (1.07) & (4.99) \\
\hline \multirow[t]{2}{*}{ Growth } & 0.013 & 0.107 & $-0.128^{* * * *}$ \\
\hline & $(0.36)$ & $(1.40)$ & $(-2.77)$ \\
\hline Firm fixed effects & Yes & Yes & Yes \\
\hline No. of Observations & 1429 & 634 & 961 \\
\hline Adjusted $\mathrm{R}^{2}$ & 0.253 & 0.321 & 0.418 \\
\hline F-statistic & 38.68 & 16.36 & 43.94 \\
\hline P-value (F-statistic) & 0.000 & 0.000 & 0.000 \\
\hline
\end{tabular}

The table reports the estimates of firm fixed effects regressions of Investment_1. All variables are defined in Table 1. t-statistics are reported in parentheses. ${ }^{* * *}$, ${ }^{* *}$, and * indicate statistical significance at the 1 percent, 5 percent, and 10 percent levels, respectively.

ordinary-least-squares (OLS) regression results are presented in Table 7 (Models 1 and 2). These results are similar to those we obtained earlier. Model (1) shows that the effect of internal financing on firm investment declines significantly during the crisis period. The Wald test (pvalue $=0.007$ ) confirms a significantly lower marginal impact of internal finance on investment relative to that of external finance. In Model (2), we compare the effect of the two financing sources in the post-crisis period. The Wald test ( $\mathrm{p}$-value $=0.308$ ) does not indicate a differential marginal impact of internal and external finance on investment.

We perform two-stage-least-squares (2SLS) regression to address the endogeneity concern between investment and internal finance. We use the previous year's level of internal finance as an instrument. The F-test for this instrument is statistically significant, indicating the validity of the chosen instrument. The predicted value of internal finance from the 
Table 7

Effect of internal and external finance on investment: Robustness check with alternative estimation techniques.

\begin{tabular}{|c|c|c|c|c|}
\hline & \multicolumn{2}{|l|}{ OLS } & \multicolumn{2}{|l|}{ 2SLS } \\
\hline & (1) & (2) & (3) & (4) \\
\hline Crisis & $\begin{array}{l}0.020^{* * * k} \\
(3.13)\end{array}$ & & $\begin{array}{l}0.022^{* * *} \\
(2.63)\end{array}$ & \\
\hline Post-crisis & & $\begin{array}{l}-0.018^{k * * * * k} \\
(-3.54)\end{array}$ & & $\begin{array}{l}-0.014^{k * *} \\
(-2.03)\end{array}$ \\
\hline Internal Finance & $\begin{array}{l}0.223^{\text {ktkk }} \\
(8.99)\end{array}$ & $\begin{array}{l}0.151^{\text {k.kx }} \\
(5.61)\end{array}$ & $\begin{array}{l}0.310^{k * k} \\
(9.67)\end{array}$ & $\begin{array}{l}0.242^{\text {***kx}} \\
(6.59)\end{array}$ \\
\hline External Finance & 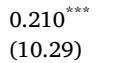 & $\begin{array}{l}0.208^{k * * * k} \\
(9.80)\end{array}$ & $\begin{array}{l}0.215^{k * * *} \\
(16.09)\end{array}$ & $\begin{array}{l}0.211^{k * * k} \\
(15.60)\end{array}$ \\
\hline Internal Finance * Crisis & $\begin{array}{l}-0.166^{* * * k} \\
(-3.18)\end{array}$ & & $\begin{array}{l}-0.149^{\text {** }} \\
(-2.36)\end{array}$ & \\
\hline Internal Finance * Post-crisis & & $\begin{array}{l}0.093^{k * k} \\
(2.02)\end{array}$ & & $\begin{array}{l}0.080 \\
(1.32)\end{array}$ \\
\hline External Finance * Crisis & $\begin{array}{l}0.022 \\
(0.49)\end{array}$ & & $\begin{array}{l}0.010 \\
(0.37)\end{array}$ & \\
\hline External Finance * Post-crisis & & $\begin{array}{l}0.025 \\
(0.63)\end{array}$ & & $\begin{array}{l}0.017 \\
(0.69)\end{array}$ \\
\hline Size & $\begin{array}{l}0.012^{* * * *} \\
(4.22)\end{array}$ & $\begin{array}{l}0.013^{* * * * k} \\
(4.37)\end{array}$ & $\begin{array}{l}0.015^{k * * k} \\
(5.02)\end{array}$ & $\begin{array}{l}0.015^{\text {***k}} \\
(5.05)\end{array}$ \\
\hline Growth & $\begin{array}{l}0.015 \\
(0.54)\end{array}$ & $\begin{array}{l}0.009 \\
(0.33)\end{array}$ & $\begin{array}{l}0.002 \\
(0.06)\end{array}$ & $\begin{array}{l}-0.0034 \\
(-0.10)\end{array}$ \\
\hline No. of Observations & 3024 & 3024 & 2710 & 2710 \\
\hline Adjusted $\mathrm{R}^{2}$ & 0.172 & 0.170 & 0.159 & 0.171 \\
\hline F-statistic & 38.09 & 44.02 & 80.53 & 81.58 \\
\hline P-value (F-statistic) & 0.000 & 0.000 & 0.000 & 0.000 \\
\hline $\begin{array}{l}\text { P-value (Wald test) for the } \\
\text { difference of interaction } \\
\text { coefficients for the } \\
\text { respective period }\end{array}$ & 0.007 & 0.308 & 0.030 & 0.369 \\
\hline F-statistic for instrument & & & 1465.87 & 1092.25 \\
\hline $\begin{array}{l}\text { P-value (F-statistic for } \\
\text { instrument) }\end{array}$ & & & 0.000 & 0.000 \\
\hline
\end{tabular}

The table reports the estimates of OLS and 2SLS regressions of Investment_1. All variables are defined in Table 1. t-statistics are reported in parentheses. ${ }^{* *}, * *$, and * indicate statistical significance at the 1 percent, 5 percent, and 10 percent levels, respectively.

first stage estimation is used as the independent variable in the second stage equation. The results, presented in Models (3) and (4) of Table 7, are similar to those obtained from fixed effects and OLS regressions. We find that the impact of internal finance on investment significantly reduced during the crisis period. However, we do not observe a significantly different impact during the post-crisis period.

We re-examine our results, distinguishing between manufacturing and non-manufacturing firms; high- and low-levered firms (those above/below the 50th percentile of the distribution); large and small firms (those with total assets above/below the 50th percentile); and high and low cash flow firms (those above/below the 50th percentile). The results show that the negative effect of the financial crisis on investment does not differ significantly between various sub-samples, except that the effect is reduced for highly levered firms. ${ }^{5}$ We also investigate the relative effects of Internal Finance and External Finance separately for the three periods, and find similar findings, except for the highly and lowly levered firms. We examine the interaction terms of each crisis year and the two financing sources (internal finance and external finance) and find qualitatively similar results to those obtained earlier.

As a final robustness check, we measure firm investment in three alternative ways. Investment_ 2 is the positive change in fixed assets plus depreciation over beginning-of-year total assets. Investment_3 is the change in tangible fixed assets plus depreciation over beginning-of-year

\footnotetext{
${ }^{5}$ Because the results are qualitatively very similar, we do not present these and some other results in separate tables for the sake of brevity. However, those tables are available from authors on request.
}

total assets. Investment_ 4 is the positive change in tangible fixed assets plus depreciation over beginning-of-year total assets. The regression results confirm the earlier findings that firm investment declines significantly both during and after the financial crisis, and that internal finance is less important for investment compared to external finance during the financial crisis. We also perform separate regressions for the pre-crisis, crisis, and post-crisis periods to examine whether internal or external finance differentially influence firm investment. These results also do not show any contradictory finding: during the financial crisis, the level of firm investment is significantly determined only by the level of external finance.

\section{Conclusion}

Throughout recent years, many European countries have constantly been suffering from various repercussions of the financial crisis. Practitioners and policymakers are much concerned with the effects of the crisis on private businesses, given the fact that a significant growth driver of the real economy are the many small and medium-sized enterprises. In this paper, we specifically focus on the investment behavior of these firms. We examine whether private SMEs have reduced the amount of investment in fixed assets as a result of the financial crisis. We also examine to what extent the decline in the availability of bank credit and the use of internal financing have affected firms' investments.

We find that small and medium-sized firms in the Netherlands significantly cut back investment expenditures in the years following the onset of the financial crisis. The univariate analysis reveals that investment per annum declined on average by 1.3 percent of total assets during the crisis period (2008-2009) and by 2 percent in the post-crisis period (2010-2012). The multivariate regression analysis that controls for various firm characteristics such as cash flows, size, and growth also indicates a significant reduction in investment.

The results of our study also show that the type of financing used is an important determinant of corporate investment. Specifically, we find a significant positive impact of both internal and external financing on the level of investments of private firms both in the pre-crisis and postcrisis periods. In contrast, during the crisis, internal financing has no impact on the investment of SMEs, whereas the availability of external financing remains a significant determinant. Our findings suggest that investments made by private firms during the financial crisis are more determined by the availability of bank financing than by the availability of internal financing. We conduct a series of additional robustness checks using alternative estimation techniques and measurement of variables. We also analyze sub-samples of firms based on manufacturing status, debt usage, firm size, and cash flows. None of these tests reveal a contradictory result. Taken together, we observe that the availability of internal funds generated by firms are not a determining factor for the investments of SMEs during the financial crisis, while the supply of bank finance remains critical to firm investment during the crisis. Our finding suggests that policymakers should be particularly concerned with ensuring the ready availability of bank lending to SMEs during an economic crisis to mitigate damaging effect on the investment decisions of private firms.

Our study is not without limitations. We do not know why internal finance becomes less influential during a crisis especially when external finance is difficult to access. Were private firms prepared to tolerate higher costs and obtain external financing in order to preserve internal funds to meet unforeseen demands resulting from the crisis? One way to shed light on this question could be to undertake a qualitative study involving a survey or interviews of owners/managers of firms. Another possibility could be to compare with a control group of firms that did not use external financing either before and after the crisis. Future research can examine those questions. Our study also did not examine (because of a lack of data) the specific characteristics of private firms before the crisis that made them more (or less) committed to keeping 
investing during the crisis. This could be relevant for policymakers to see where best to intervene to sustain business investment. Another limitation of the study comes from its focus on one country and therefore our hesitancy in generalizing the applicability of the results to other countries. However, we believe that our findings would be applicable to European private SMEs that operate in a bank-based financial system. Although collecting data on private enterprises can be a colossal task, future research using cross-country data would yield interesting results.

\section{Acknowledgement}

We are very grateful to the Associate Editor (Claire Crutchley Lending) and two anonymous reviewers for many useful remarks during the review process. We also thank Marc Deloof, Piet Duffhues, Iftekhar Hasan, Joris Knoben and the participants at the International Academy of Management and Business Conference (Washington, USA), the Global Business and Finance Research Conference (Melbourne, Australia), the Economics of Entrepreneurship and Innovation Workshop (Trier, Germany), the Academy of Management Conference (Atlanta, USA) and the Finance \& Accounting Seminar at the University of Twente for many helpful comments on earlier versions of the paper. All remaining errors are our own.

\section{References}

Agliardi, E., Agliardi, R., \& Spanjers, W. (2016). Corporate financing decisions under ambiguity: Pecking order and liquidity policy implications. Journal of Business Research, 69, 6012-6020.

Akbar, S., Rehman, S., \& Ormrod, P. (2013). The impact of recent financial shocks on the financing and investment policies of UK private firms. International Review of Financial Analysis, 26, 59-70.

Akiyoshi, F., \& Kobayashi, K. (2010). Banking crisis and productivity of borrowing firms: Evidence from Japan. Japan and the World Economy, 22, 141-150.

Almeida, H., Campello, M., \& Laranjeira, B. (2011). Corporate debt maturity and the real effects of the 2007 credit crisis. Critical Finance Review, 1, 3-58.

Almeida, J. R., \& Eid, W., Jr. (2014). Access to finance, working capital management and company value: Evidences from Brazilian companies listed on BM \& FBOVESPA. Journal of Business Research, 67, 924-934.

Asker, J., Farre-Mensa, J., \& Ljungqvist, A. (2015). Corporate investment and stock market listing: A puzzle? Review of Financial Studies, 28, 342-390.

Ayyagari, M., Beck, T., \& Demirgüç-Kunt, A. (2007). Small and medium enterprises across the globe. Small Business Economics, 29, 415-434.

Badertscher, B., Shroff, N., \& White, H. (2013). Externalities of public firm presence: Evidence from private firms' investment decisions. Journal of Financial Economics, 109, 682-706.

Becchetti, L., Castelli, A., \& Hasan, I. (2010). Investment-cash flow sensitivities, credit rationing and financing constraints in small and medium-sized firms. Small Business Economics, 35, 467-497.

Beck, T., Demirguc-Kunt, A., \& Maksimovic, V. (2008). Financing patterns around the world: Are small firms different? Journal of Financial Economics, 89, 467-487.

Bastos, R., \& Pindado, J. (2013). Trade credit during a financial crisis: A panel data analysis. Journal of Business Research, 66(5), 614-620.

Berger, A., \& Udell, G. (1998). The economics of small business finance: The roles of private equity and debt markets in the financial growth cycle. Journal of Banking \& Finance, 22, 613-674.

Bigelli, M., Martín-Ugedo, J., \& Sánchez-Vidal, F. (2014). Financial conservatism of private firms. Journal of Business Research, 67, 2419-2427.

Bo, H., Driver, C., \& Lin, H. C. (2014). Corporate investment during the financial crisis: Evidence from China. International Review of Financial Analysis, 35, 1-12.

Chen, H. J., \& Hsu, H. T. (2005). The role of firm size in controlling output decline during the Asian financial crisis. Journal of Economic Development, 30, 103-129.

Danielson, M., \& Scott, J. (2007). A note on agency conflicts and the small firm investment decision. Journal of Small Business Management, 45, 157-175.

Degryse, H., de Goeij, P., \& Kappert, P. (2012). The impact of firm and industry characteristics on small firms' capital structure. Small Business Economics, 38, 431-447.

de Goeij, P., \& Duffhues, P. (2010). Het investerings/financieringsgedrag van rechtspersoonlijk-heid bezittende ondernemingen. CentER Applied Research, Tilburg University, 172.

de la Torre, A., Martínez Pería, M., \& Schmukler, S. (2010). Bank involvement with SMEs:
Beyond relationship lending. Journal of Banking \& Finance, 34, 2280-2293.

Du, J., Guariglia, A., \& Newman, A. (2015). Do social capital building strategies influence the financing behavior of Chinese private small and medium-sized enterprises? Entrepreneurship Theory and Practice, 39, 601-631.

Duchin, R., Ozbas, O., \& Sensoy, B. (2010). Costly external finance, corporate investment, and the subprime mortgage credit crisis. Journal of Financial Economics, 97, 418-435.

Fazzari, S., Hubbard, R., \& Petersen, B. (1988). Financing constraints and corporate investment. Brookings Papers on Economic Activity, 1, 141-195.

Firth, M., Malatesta, P. J., Xin, Q., \& Xu, L. (2012). Corporate investment, government control, and financing channels: Evidence from China's listed companies. Journal of Corporate Finance, 18, 433-450.

Francis, B., Hasan, I., \& Wu, Q. (2012). Do corporate boards matter during the current financial crisis? Review of Financial Economics, 21, 39-52.

Gregory, B., Rutherford, M., Oswald, S., \& Gardiner, L. (2005). An empirical investigation of the growth cycle theory of small firm financing. Journal of Small Business Management, 43, 382-392.

Guariglia, A. (2008). Internal financial constraints, external financial constraints, and investment choice: Evidence from a panel of UK firms. Journal of Banking \& Finance, 32, 1795-1809.

Gujarati, D. (2012). Basic Econometrics (International edition). New York: McGraw Hill.

Honjo, Y., \& Harada, N. (2006). SME policy, financial structure and firm growth: Evidence from Japan. Small Business Economics, 27, 289-300.

Kahle, K., \& Stulz, R. (2013). Access to capital, investment, and the financial crisis. Journal of Financial Economics, 110, 280-299.

Kasahara, T. (2008). Severity of financing constraints and firms' investments. Review of Financial Economics, 17, 112-129.

Kim, D., Lee, Y., \& Park, K. (2002). Credit crunch and shocks to firms: Korean experience under the Asian financial crisis. Emerging Markets Review, 3, 195-210.

Kirchhoff, B., Newbert, S., \& Hasan, I. (2007). The influence of university R\&D expenditures on new business formations and employment growth. Entrepreneurship Theory and Practice, 31, 543-559.

Laeven, L. \& Valencia, F. (2012). Systemic banking crises database: An update. IMF Working Paper No. 12/163.

Lee, S., Park, G., \& Yoon, B. (2010). Open innovation in SMEs - an intermediated network model. Research Policy, 39, 290-300.

López-Gracia, J., \& Mestre-Barberá, R. (2011). Tax effect on Spanish SME optimum debt maturity structure. Journal of Business Research, 64, 649-655.

Michaelas, N., Chittenden, F., \& Poutziouris, P. (1999). Financial policy and capital structure choice in UK SMEs: Empirical evidence from company panel data. Small Business Economics, 12, 113-130.

Mortal, S., \& Reisel, N. (2013). Capital allocation of public and private firms. Journal of Financial and Quantitative Analysis, 48, 77-103.

Nguyen, T., Nguyen, H., \& Xiangkang, Y. (2015). Corporate governance and corporate financing and investment during the 2007-2008 financial crisis. Financial Management, 44, 115-146.

Ogawa, K., \& Tanaka, T. (2013). The global financial crisis and small- and medium-sized enterprises in Japan: How did they cope with the crisis. Small Business Economics, 41, 401-417.

Petersen, M., \& Rajan, R. (1994). The benefits of lending relationships: Evidence from small business data. Journal of Finance, 49, 3-37.

Psillaki, M., \& Eleftheriou, K. (2015). Trade credit, bank credit, and flight to quality: Evidence from French SMEs. Journal of Small Business Management, 53, 1219-1240.

Rahaman, M. (2011). Access to financing and firm growth. Journal of Banking \& Finance, $35,709-723$.

Rousseau, P., \& Kim, J. (2008). A flight to Q? Firm investment and financing in Korea before and after the 1997 financial crisis. Journal of Banking \& Finance, 32, 1416-1429.

Sogorb Mira, F. (2005). How SME uniqueness affects capital structure: Evidence from a 1994-1998 Spanish data panel. Small Business Economics, 25, 447-457.

Vermoesen, V., Deloof, M., \& Laveren, E. (2013). Long-term debt maturity and financing constraints of SMEs during the global financial crisis. Small Business Economics, 41, $433-448$.

Wang, D. (2010). Corporate investment, financing, and dividend policies in the high-tech industry. Journal of Business Research, 63(5), 486-489.

Yang, C., Baker, H., Chou, L., \& Lu, B. (2009). Does switching from NASDAQ to the NYSE affect investment cash flow sensitivity? Journal of Business Research, 62(10), 1007-1012.

Siraz Zubair is an Assistant Professor of Finance.

Rezaul Kabir is a Professor of Corporate Finance and Risk Management.

Xiaohong Huang is an Assistant Professor of Finance.

All three authors are at the Department of Finance and Accounting, Faculty of Behavioral, Management \& Social Sciences, University of Twente, The Netherlands. 